\title{
Luis Castellví Laukamp, Hispanic Baroque Ekphrasis: Góngora, Camargo, Sor Juana, Cambridge, Legenda, 2020 (Studies in Hispanic and Lusophone Cultures, 38), 236 pp. ISBN: 978-1-781888-15-5
}

\section{Laura Yadira Munguía Ochoa}

Universidad Panamericana Departamento de Humanidades MÉXICO

Imunguia@up.edu.mx

[Hipogrifo, (issn: 2328-1308), 9.1, 2021, pp. 1369-1372]

Recibido: 03-02-2021 / Aceptado: 09-02-2021

DOI: http://dx.doi.org/10.13035/H.2021.09.01.75

El barroco es uno de los momentos más luminosos de la literatura española, la riqueza inaudita de sus obras y sus autores sin duda sigue atrayendo el interés de lectores y críticos de todas partes del mundo. El Siglo de Oro y en específico lo más granado del barroco no solo se desarrolló en España sino también en sus posesiones ultramarinas en América. Grandes autores considerados dentro de la estirpe de la metrópoli nunca pisaron tierras europeas.

Unido al interés de la literatura española y novohispana está también el del barroco en otra de sus facetas, la pintura: este es el caso del investigador de la Universidad de Manchester Luis Castellví Laukamp, quien hace un excelente estudio acerca de la écfrasis encontrada dentro de tres poemas cumbre de la literatura en español, a saber, las Soledades de Luis de Góngora (c. 1613), San Ignacio de Loyola fundador de la Compañía de Jesús, poema heroico de Hernando Domínguez Camargo (1666), y el Primero sueño de sor Juana Inés de la Cruz (1692).

En este excelente libro, el autor plantea la visión pictográfica de la écfrasis que se muestra de manera palpable en las obras antes señaladas, las tres, claramente visuales pintan por medios de sus versos-paisajes, cuadros y escenarios que llevan al lector del poema a algo más allá de la pura descripción poética y versificada. Los 
tres, para Castellví, son una suerte de pintores que se desarrollan, no con el pincel, sino con la pluma, una pluma bastante afilada e ingeniosa que les permite inmortalizarse para la posteridad en el legado de las letras universales: «They would become the greatest Creole Gongorist poets» (p. 71).

El verso estilizado, sublime y erudito de Góngora caló hondo en la Nueva España, sedienta siempre de igualarse a la metrópoli. Tradicionalmente, la idea de la literatura novohispana como copia o extensión de la española ha sido la idea que por lo general ha permeado en la crítica literaria y la historiografía. Sin embargo, en últimos tiempos se ha dado más en pensar que no estamos ante una mímesis, ni una literatura española escrita en América, sino una verdadera producción nacional, nacida de la mezcla, mestiza, criolla, y de tintes parecidos, pero distintos a los de la Península Ibérica. Al menos esta es la visión que maneja Castellví en su libro: obra de una estructura y estilo igual, pero distinta en contenido, la literatura novohispana no puede separarse de la mezcla con lo indiano por estar amalgamado esencialmente a ello.

Dentro de esta perspectiva, la poesía novohispana tiene sus propios rasgos, aunque íntimamente ligados al barroco español, un ejemplo de esto es, como menciona Castellví, una poesía gongorista, dada más a la palabra que a la idea, más a la artesanía del lenguaje preciosista y difícil que a la reflexión íntima y elevada. Por lo tanto, don Luis de Góngora será un tremendo gestador de diferencias tanto en España como en América.

El gongorismo americano es evidente, esa búsqueda por lo original, visual y recargado aparece en muchos de los poetas sobre todo de la Nueva España y Nueva Granada, ejemplo de ello son sor Juana y Camargo. Es por esta cercanía que Luis Castellví hace notorio en su libro cómo los mecanismos poéticos usados por Góngora van a ser reutilizados con otro estilo en tierras americanas, estilo que obedece a sus propias intencionalidades. Tal como el autor señala: «these viceregal poets understood the overwhelming visual power of Gongorism and deployed it for spiritual purposes» (p. 5). Para nuestro autor, tanto Camargo como sor Juana son los más grandes gongoristas de este lado del Atlántico, llevando a un nivel de altísima calidad el poder visual de Góngora, sobre todo el que despliega en sus Soledades.

Uno de los mayores logros de Hispanic Barroque Ekphrasis es la visión analítica que logra Castellví entre producciones artísticas diferentes, a saber, Góngora con su técnica visual y detallada, sor Juana y Camargo con la herencia diferenciada de los cánones poéticos españoles y la pintura novohispana, hecha muchas veces sobre moldes mandados a la Nueva España. La pintura del Nuevo Mundo pintaba sobre bocetos o copiaba pinturas, pero sin duda narraba visualmente sus propias elucubraciones religiosas e incluso místicas. Esta relación entre la literatura y la pintura es lo que hace original a esta obra aquí comentada. 
Algo muy parecido sucede con los poetas, según Castellví, pues, aunque toman como marco las estructuras visuales de Góngora, el resultado de la écfrasis en Camargo y sor Juana sin duda es de otro tinte y otro temple, Camargo se muestra bajo un halo religioso y la monja se encubre bajo uno esotérico. En efecto, Camargo tiende a la descripción piadosa con imágenes religiosas (como el Crucifijo de Manresa, pp. 71-98); mientras que la Jerónima apunta al egipcianismo del padre Kircher, en quien los jeroglifos nutren su imaginación (p. 158).

Desde el punto de vista de Castellví, estos dos autores merecen un mayor acercamiento por parte de los investigadores en el tema de la écfrasis en relación con el gongorismo, relación que es evidente para nuestro autor y que se esmera en mostrar; sobre todo en esta comunicación íntima entre lo visual, lo poético y lo exótico. En su libro, el autor logra dejarnos ver el importante juego de ida y venida que hay del barroco español al americano y de este a la pintura y viceversa.

En resumen, lo que nos propone aquí Castellví es que el gongorismo en sí y el heredado en América, no es solo una forma de entender el lenguaje culto, sino también una forma de ver el mundo como una obra de arte. Desde este punto de vista, esta serie de relaciones sería también una diglosia, al hacer convivir en versos la visión de dos mundos y dos realidades distintas.

Después de la introducción, el autor divide su libro en tres partes por demás interesantes, que se fraccionan a su vez en dos capítulos por cada apartado. La primera parte está dedicada al análisis de las características poéticas de Góngora, sobre todo en lo que tiene que ver con las écfrasis introducidas en las Soledades; ya que «this Weltanschauung is at odds with the Soledades, where peace is praised as the most fitting state for human creativity» (p. 26). Como se ha dicho antes, el estudio analógico que hace Castellví respecto a las obras pictóricas guarda, desde su perspectiva de frontera, las mismas características que los poemas. Resalta en estos capítulos la visión de una teicoscopía a partir de la écfrasis usada por Góngora, es decir, la descripción detallada de un paisaje visto desde un punto alto del panorama: «Teichoscopy may also operate as a poetic 'archive', since the characters seen from above are named and thus their martial deeds preserved for posterity. From an aesthetic and historical viewpoint, teichoscopy is a way of presenting wars as an image of cosmic order» (p. 25).

El libro de Castellví está ampliamente documentado en la bibliografía crítica y se posiciona eruditamente entre la literatura y el arte pictórico, teniendo en todo momento como puente el estilo de Góngora que transformó la poética barroca en ambos lados del Atlántico. El aparato documental y pictográfico analizado da soporte a esta obra, que indudablmente quiere posicionarse como un referente del tema.

La segunda parte del libro la dedica Castellví al estudio del San Ignacio de Camargo, donde compara y ejemplifica la forma en la que desarrolla la écfrasis respecto de un crucifijo que está visto desde una perspectiva baja, es decir, al contrario de la écfrasis en las Soledades de Góngora que es una teicoscopía; lo cual nos permite acceder a una perspectiva amplia entre la literatura y el arte gráfico. 
La tercera sección trata, en el mismo sentido de las anteriores, de las écfrasis incluidas por sor Juana en el Primero sueño, la visión de Castellví acerca de las descripciones de la Décima Musa es que, mientras Góngora y Camargo describen la realidad, un paisaje y una obra de arte, ella describe un mundo inexistente, cercano a ese mundo de las ideas que plantea Platón, dándonos una panorámica distinta del entendimiento de esta obra maestra de sor Juana.

En general, la aportación que hace Luis Castellví es de un destacado avance en materia de análisis poético, abre nuevas perspectivas y acercamientos a los estudios retóricos de autores imprescindibles para la literatura áurea. Sin duda, la lectura de este libro es una buena inversión para el conocimiento de la riqueza poética del siglo XVII. 